\title{
Arsenic quantification techniques and ISO/IEC 17025 accreditation in Brazil
}

\section{Jefferson Luiz Antunes Santos ${ }^{1, *}$, Jader Galba Busato ${ }^{2}$, Rodrigo de Almeida Heringer ${ }^{3}$, Juscimar da Silva ${ }^{4}$ and Leonardo Barros Dobbss ${ }^{1}$}
${ }^{1}$ Federal University of Vales Jequitinhonha e Mucuri (UFVJM). Institute of Agricultural Sciences (ICA). Av. Universitária, 1000, Unaí-MG, Brazil (CEP 38610-000).*E-mail: jefferson.antunes@ufvjm.edu.br.
${ }^{2}$ University of Brasilia (UnB). Faculty of Agronomy and Veterinary Medicine. University Campus Darcy Ribeiro. Sciences Central Institute. Brasília-DF, Brazil (CEP 70910-900).
${ }^{3}$ Federal University of Goiás (UFG). Institute of Science and Technology (ICT). Rua Mucuri, 920. Parque Itatiaia. Aparecida de Goiânia-GO, Brazil (CEP 74968-755).
${ }^{4}$ Brazilian Agricultural Research Corporation (Embrapa). Embrapa Hortaliças. Fazenda Tamanduá. Parque Estação Biológica. Brasília-DF, Brazil (CEP 70770-901).

\begin{abstract}
The importance of arsenic (As) quantification in environmental compartments is due to its risks to ecosystems and public health. There are reports of high concentrations of this metalloid in Brazil and technological differences between states are observed. The objective of this work was to present and discuss current scenarios of accreditation and compare the limit of quantification (LOQ) of As by analytical technique in Brazil. Data from accredited laboratories were collected on Inmetro website and in state metrological networks and then grouped and analyzed by state, matrix and analytical technique. There are large discrepancies between the number of laboratories per state and a good correlation with gross domestic product (GDP). Almost all laboratories have a LOQ less than the environmental limits. The observed list of techniques sorted from lowest to highest LOQ values is: for liquid samples ICP MS (inductively coupled plasma mass spectrometry), ET AAS (electrothermal atomic absorption spectrometry), HG AAS (hydride generation combined with atomic absorption spectrometry) or HG ICP OES (hydride generation combined with inductively coupled plasma optical emission spectrometry) and UV VIS (visible ultraviolet spectroscopy); for solids samples HG ICP OES, ICP MS, HG AAS, ET AAS and FAAS (flame atomic absorption spectrometry); and for bioindicators ICP MS, HG ICP OES. Analysis of As species is accredited in only one laboratory, but does not include all species.
\end{abstract}

Keywords: Hydride generation; Environmental laboratories; Limit of detection; Spectrometry; Speciation; Chromatography.
Received

November 06, 2019

Accepted

December 23, 2019

Released

December 31, 2019

Acesso aberto

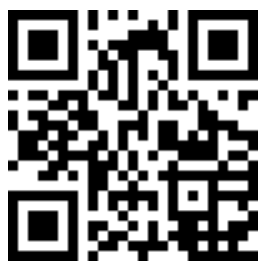

ORCID

(1) 0000-0001-9308-6373 Jefferson Luiz Antunes Santos

(D) 0000-0003-2810-7769 Jader Galba Busato

(ㄷ) 0000-0001-7035-606X Rodrigo de Almeida Heringer 
Resumo. Técnicas de quantificação de arsênico e acreditação ISO/IEC 17025 no Brasil. A importância da quantificação do arsênico (As) nos compartimentos ambientais deve-se aos riscos para os ecossistemas e para a saúde pública. Há relatos de altas concentrações desse metaloide no Brasil e diferenças tecnológicas entre estados são observadas. 0 objetivo deste trabalho foi apresentar e discutir os cenários atuais de acreditação e comparar o limite de quantificação (LOQ) de As pelas técnicas analíticas no Brasil. Os dados dos laboratórios credenciados foram coletados no site do Inmetro e nas redes metrológicas estaduais e, em seguida, agrupados e analisados por estado, matriz e técnica analítica. Existem grandes discrepâncias entre o número de laboratórios por estado e uma boa correlação com o produto interno bruto (PIB). Quase todos os laboratórios têm um LOQ menor que os limites ambientais. A lista observada de técnicas classificadas dos menores aos mais altos valores de LOQ é: para amostras líquidas ICP MS (espectrometria de massa de plasma indutivamente acoplado), ET AAS (espectrometria de absorção atômica eletrotérmica), HG AAS (geração de hidreto combinada com espectrometria de absorção atômica) ou HG ICP OES (geração de hidreto combinado com espectrometria de emissão óptica de plasma acoplada indutivamente) e UV VIS (espectroscopia ultravioleta visível); para amostras de sólidos HG ICP OES, ICP MS, HG AAS, ET AAS e FAAS (espectrometria de absorção atômica por chama); e para bioindicadores ICP MS, HG ICP OES. A análise das espécies As é creditada em apenas um laboratório, mas não inclui todas as espécies.

Palavras-chave: Geração de hidreto; Laboratórios ambientais; Limite de detecção; Espectrometria; Especiação; Cromatografia.
๑ 0000-0002-8757-6170 Juscimar da Silva

(1) 0000-0003-0465-4186

Leonardo Barros

Dobbss

\section{Introduction}

The environmental risk of arsenic (As) to ecosystems and public health is a fact in a large number of countries around the world (Bundschuh et al., 2012). The metalloid can be responsible for various dermatological, cardiovascular, pulmonary, reproductive, neurological and tumorigenesis complications in many parts of the body (Abdul et al., 2015).

Analytical techniques for quantification of As on environmental samples typically include atomic absorption, atomic emission and mass spectrometry and, X-ray fluorescence and visible-ultraviolet spectroscopy techniques (Ma et al., 2014; Sankararamakrishnan and Mishra, 2018). These techniques may include flame atomizers, hydride generators and electrothermal devices, such as the graphite furnace (Sankararamakrishnan and Mishra, 2018). Analytical techniques s approved by USEPA include inductively coupled plasma optical emission spectrometry (ICP OES), inductively coupled plasma mass spectrometry (ICP MS), hydride generation combined with atomic absorption spectrometry (HG AAS) and electrothermal atomic absorption spectrometry (ET AAS), with quantification limits ranging from 0.5 to $50 \mu \mathrm{g} \mathrm{L}^{-1}$ (Ma et al. 2014).

Recent studies have used ICP MS (Bolea-Fernandez et al., 2015; Oroian et al., 2016; Kaya and Turkoglu, 2017; Machado et al., 2017; De La Cruz et al., 2018), HG AAS (Waterlot and Douay, 2015), ET AAS (Hassanpoor et al., 2015; 
Oliveira et al., 2016; Souza et al., 2016; Pereira et al., 2016), hydride generation combined with inductively coupled plasma optical emission spectrometry HG ICP OES (Kim et al., 2019), hydride generation combined with atomic fluorescence spectrometry (HG AFS) (Wang et al., 2016), microwave induced plasma optical emission spectrometry (MIP OES) (Gallego Ríos et al., 2018), visible ultraviolet spectroscopy (UV VIS) (Gürkan et al., 2015), total reflection X-ray fluorescence (TXRF) (Pierangeli et al., 2015) and portable X-ray fluorescence (PXRF) (García-Rico et al., 2019; Kim et al., 2019).

In addition to total As quantification, speciation techniques are important to detect and quantify many of As species, which may occur in organic or inorganic forms and in different valence states, with implications on their bioavailability and toxicity (Abdul et al., 2015; Moe et al., 2016; Liu et al., 2018). Some hyphenated techniques consider chromatography and capillary electrophoresis (Khan et al., 2015; Ma et al., 2016; Cheng et al., 2018; García-Rico et al., 2019); ion chromatography (Zhu et al., 2017), ultraviolet spectroscopy and capillary electrophoresis (CE UV) (Lee et al., 2018) for the separation of species.

The maximum stablished limit for drinking water, groundwater and class 1 freshwater is $10 \mu \mathrm{g} \mathrm{L}^{-1}$ (Brasil, 2005, 2009, 2017). For effluents, the limit is $500 \mu \mathrm{g} \mathrm{L}^{-1}$ (Brasil, 2011). In soils, the value of prevention (VP) is $15 \mathrm{mg} \mathrm{kg}^{-1}$, the value of agricultural investigation is $35 \mathrm{mg} \mathrm{kg}^{-1}$, residential investigation is $55 \mathrm{mg} \mathrm{kg}^{-1}$ and the industrial value is $150 \mathrm{mg} \mathrm{kg}^{-1}$ (Brasil, 2009). The resolutions of National Environment Council (CONAMA), which enforce the accepted limits, also require that the analyzes for characterization and monitoring be performed by laboratories accredited by the National Institute of Metrology, Standardization and Industrial Quality (INMETRO) (Brasil, 2009, 2011). However, there are no standards for bioindicators, air quality and As species.

Brazil has historical regional differences that are reflected in the access to technologies (Santos et al., 2014). According to Grochau et al. (2017) there is a strong correlation between the gross domestic product (GDP) of counties in the Americas and the number of ISO 17025 accredited laboratories.

In Brazil, the main high As concentrations occur in Minas Gerais state (Bundschuh et al., 2012), especially correlated to gold deposits in the Iron Quadrangle (Borba et al., 2003; Varejão et al., 2011; Costa et al., 2015; Silva et al., 2018) and in the surroundings the of city of Paracatu (Ono et al., 2012; Rezende et al., 2015; Bidone et al., 2018). In these regions the presence of As is associated with natural deposits of gold, where it is predominantly contained in sulfide minerals such as arsenopyrite and pyrite (Deschamps et al., 2002).

Keeping this in view, the objective of this work was to present and discuss current scenarios of accreditation and compare the limit of quantification (LOQ) of As by analytical techniques in Brazil.

\section{Methodology}

Data on accredited laboratories, LOQ and analytical techniques were collected in July, 2018 from Inmetro's website (Inmetro 2018) and state metrological networks (RMMG, 2018; Rede Metrológica do Rio Grande do Sul, 2018). Laboratories were grouped by state, matrix and analytical technique. Matrices were grouped by the sample type as liquid (drinking water, raw water, underground water, for human consumption, treated, saline, brackish, residual, effluent, solubilized extract and leachate and liquid waste), solid (soil, sediment, solid waste, industrial, rock, sludge) and bioindicators (plant tissue, mussel, aquatic, terrestrial and plant organisms). The correlation between state's GDP and number of accredited laboratories was based on Pearson correlation coefficient using Excel software (Office 365, 1903 version). Descriptive analysis of the analytical techniques by state and matrix. 


\section{Results and discussion}

In Brazil, there are 1081 accredited laboratories, of which 385 offer environmental tests and only 102 analyze As. The highest number of environmental laboratories is concentrated in the Southeast and South regions, which accounts for $89 \%$ of the total. For instance, São Paulo (SP) state respond for almost $53 \%$. The number is even higher when considering As analysis, with $96 \%$ of the laboratories located in the South and Southeast regions, $67 \%$ in SP. Northeast region has only one laboratory in Bahia (BA) while the North has no. Figure 1 shows the distribution of laboratories and GDP by state.

A strong positive correlation (Pearson correlation) was found between the number of accredited laboratories and GDP, as also observed by (Grochau et al., 2017). The highest correlation occurred with the testing laboratories $(r=0.97)$, followed by testing environmental laboratories $(r=0.94)$ and finally those performing As analyses $(r=0.92)$.

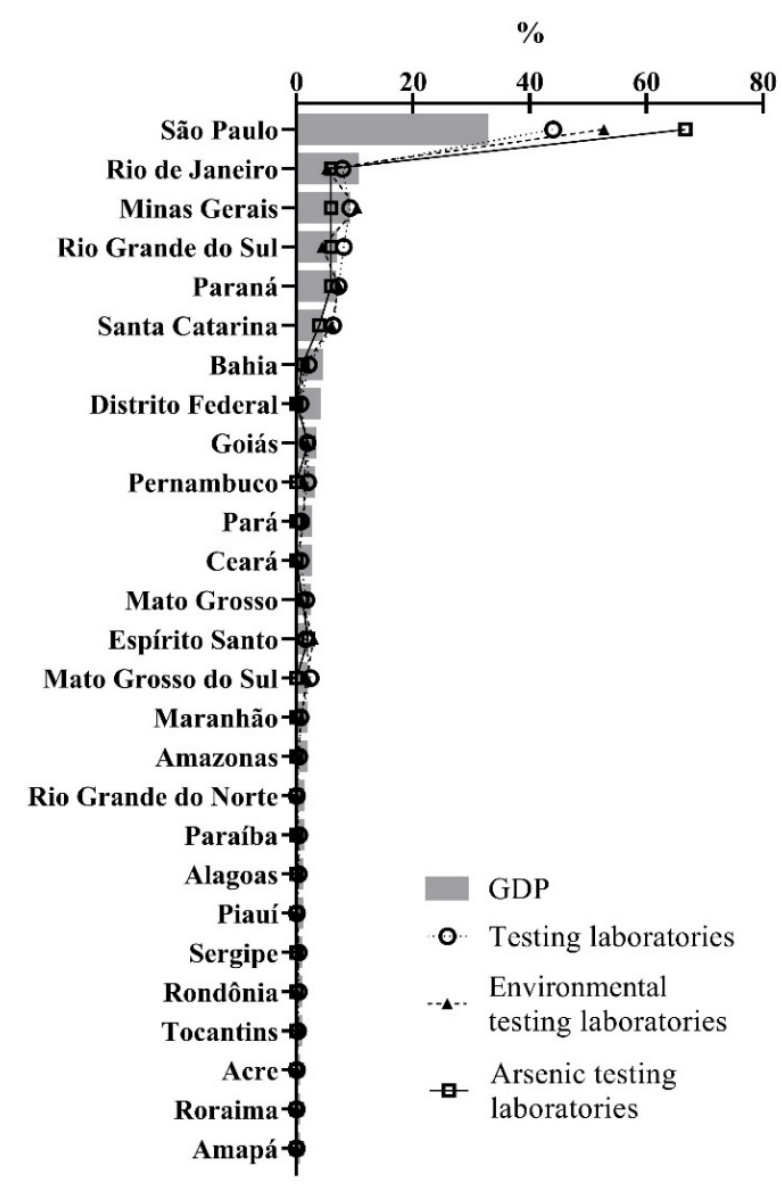

Figure 1. Percentage of the national number of accreditations of testing laboratories (1081), testing environmental (385), arsenic testing (102) and GDP (gross domestic product), by State, in Brazil.

HG ICP OES or HG AAS are most common techniques used for quantify As in small content (Table 1), corresponding to $80.3 \%$ of the accreditations. The ones 
with larger investments and with higher analytical sensitivity, such as ICP MS and ET AAS, accounted for $17.2 \%$ and those with lower sensitivity, such as flame atomic absorption spectrometry (FAAS) and UV VIS, only 2.5\%. More sensitive techniques are present in only 5 states (SP, MG, RJ, RS and PR).

Table 1. Analytical techniques for As quantification of As used in accredited laboratories in different states from Brazil.

\begin{tabular}{lcccccccccc}
\hline \multirow{2}{*}{ Technique } & \multicolumn{10}{c}{ States } \\
\cline { 2 - 24 } & SP & MG & RJ & RS & PR & SC & ES & BA & GO & MT \\
\hline ICP MS & 4 & 2 & 1 & 1 & 1 & 0 & 0 & 0 & 0 & 0 \\
ET AAS & 8 & 1 & 0 & 2 & 1 & 0 & 0 & 0 & 0 & 0 \\
HG AAS & 20 & 7 & 3 & 5 & 2 & 1 & 0 & 1 & 1 & 0 \\
HG ICP OES & 41 & 4 & 3 & 0 & 3 & 3 & 2 & 0 & 1 & 1 \\
UV VIS & 2 & 0 & 0 & 0 & 0 & 0 & 0 & 0 & 0 & 0 \\
FAAS & 0 & 0 & 0 & 0 & 1 & 0 & 0 & 0 & 0 & 0 \\
\hline
\end{tabular}

Considering only laboratories accredited for As analysis, 89\% have accreditation in liquid matrices, $42 \%$ in solids, $10 \%$ in gases and $2 \%$ in bioindicators. That distribution probably stems from a greater concern with water potability. Fig. 2 shows the LOQ (Limit of quantification) for As per analytical technique, in the three different matrices: liquid, solid and bioindicator samples.

Almost all laboratories presented a LOQ in accordance with environmental threshold for water, effluent and soil. Many laboratories (31) has a value equal to the potability standard (Brasil, 2017) (Figure 2a), potentially indicating that it is used as a target. Only one laboratory presented a LOQ greater than the potability standard and is therefore not applicable for this purpose (Figure 2a). This laboratory utilizes the HG AAS, but the occurrence does not prove to be a limitation since the other laboratories and other studies (Borba et al., 2004; Akter et al., 2005; Waterlot and Douay, 2015) presented considerably lower values. Three laboratories presented LOQ values greater than the VP (15 mg kg-1) (Brasil, 2009) (Figure 2b), of which two used HG ICP OES and one FAAS. As with other laboratories, which obtained LOQ values below the VP using HG ICP OES, the occurrence is not a limitation of the technique. Only one laboratory uses FAAS and presents LOQ values above the VP. Other authors also obtained LOQ values near or even above the VP, such as 12.8 mg kg-1 with ICP OES (Paye et al., 2010) and $33.3 \mathrm{mg} \mathrm{kg}^{-1}$ with PXRF (García-Rico et al., 2019).

Techniques sorted from lowest to highest LOQ, considering the lowest LOQ, was similar among the matrices. In the case of liquid matrices, it was: ICP MS (40 $\left.\eta \mathrm{g} \mathrm{L}^{-1}\right)$, ET AAS (50 $\left.\eta \mathrm{g} \mathrm{L}^{-1}\right)$, HG AAS or HG ICP OES (100 $\left.\eta \mathrm{g} \mathrm{L}^{-1}\right)$ and UV VIS $\left(4 \mu \mathrm{g} \mathrm{L}^{-1}\right)$ (Fig. 2a). In solid matrices: HG ICP OES (1 $\left.\mu \mathrm{g} \mathrm{kg}^{-1}\right)$, ICP MS $\left(1.5 \mu \mathrm{g} \mathrm{kg}^{-1}\right)$, HG AAS (10 $\left.\mu \mathrm{g} \mathrm{kg}^{-1}\right)$, ET AAS $\left(50 \mu \mathrm{g} \mathrm{kg}^{-1}\right)$ and FAAS (100 mg $\mathrm{kg}^{-1}$ ) (Figure 2b). In bioindicators: ICP MS $\left(10 \mu \mathrm{g} \mathrm{kg}^{-1}\right)$ and HG ICP OES $\left(50 \mu \mathrm{g} \mathrm{kg}^{-1}\right)$ (Figure 2c). In a study comparing practically the same analytical techniques, Hung et al. (2004) observed a similar sequence (ICP MS, ET AAS, HG AFS, HG AAS and HG ICP OES) compared with the present study, except for UV VIS which was not observed. Yogarajah and Tsai (2015) also obtained a lower LOQ for ICP MS (ICP MS=AFS $<$ AAS) and Akter et al. (2005) observed a lower LOQ for liquid chromatography (LC) combined with ICP MS than for HG AAS (LC ICP $\mathrm{MS}<\mathrm{HG}$ $\mathrm{AAS}<\mathrm{CE} U \mathrm{UV}$ ). 
$\mathbf{a}$

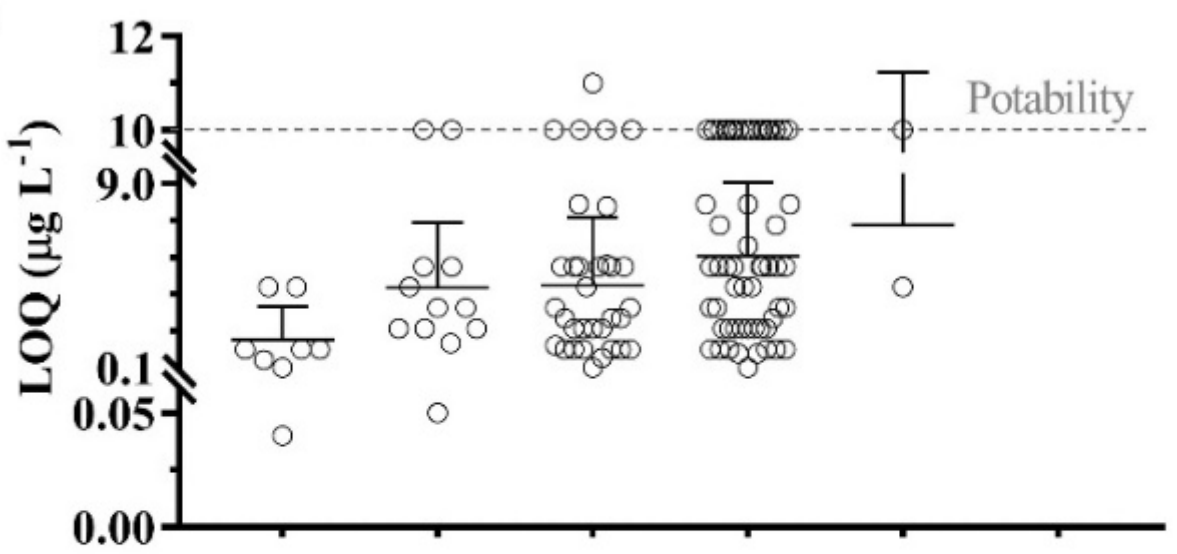

b

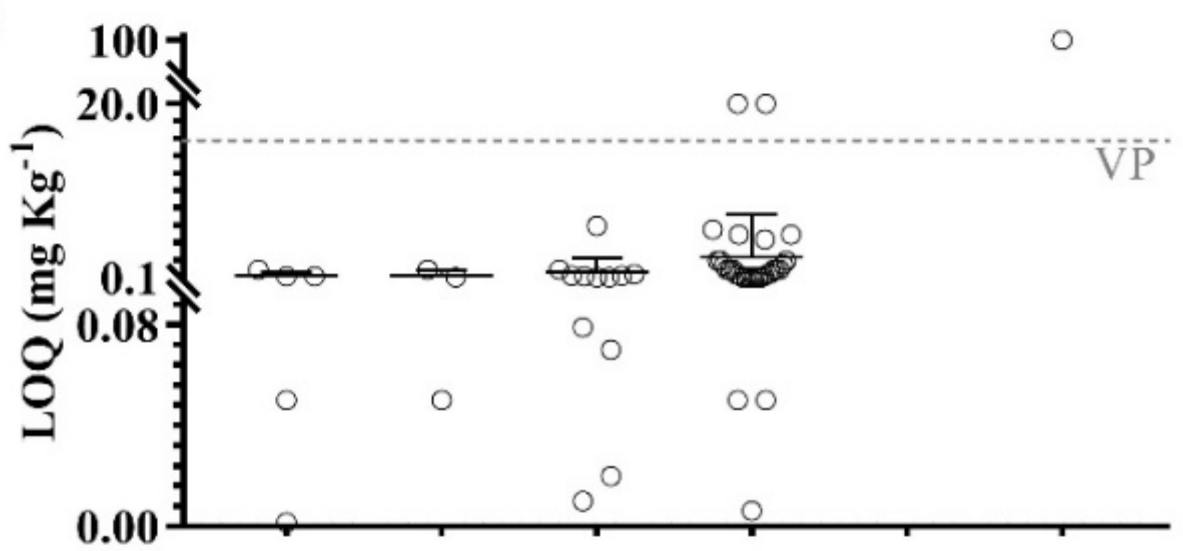

c

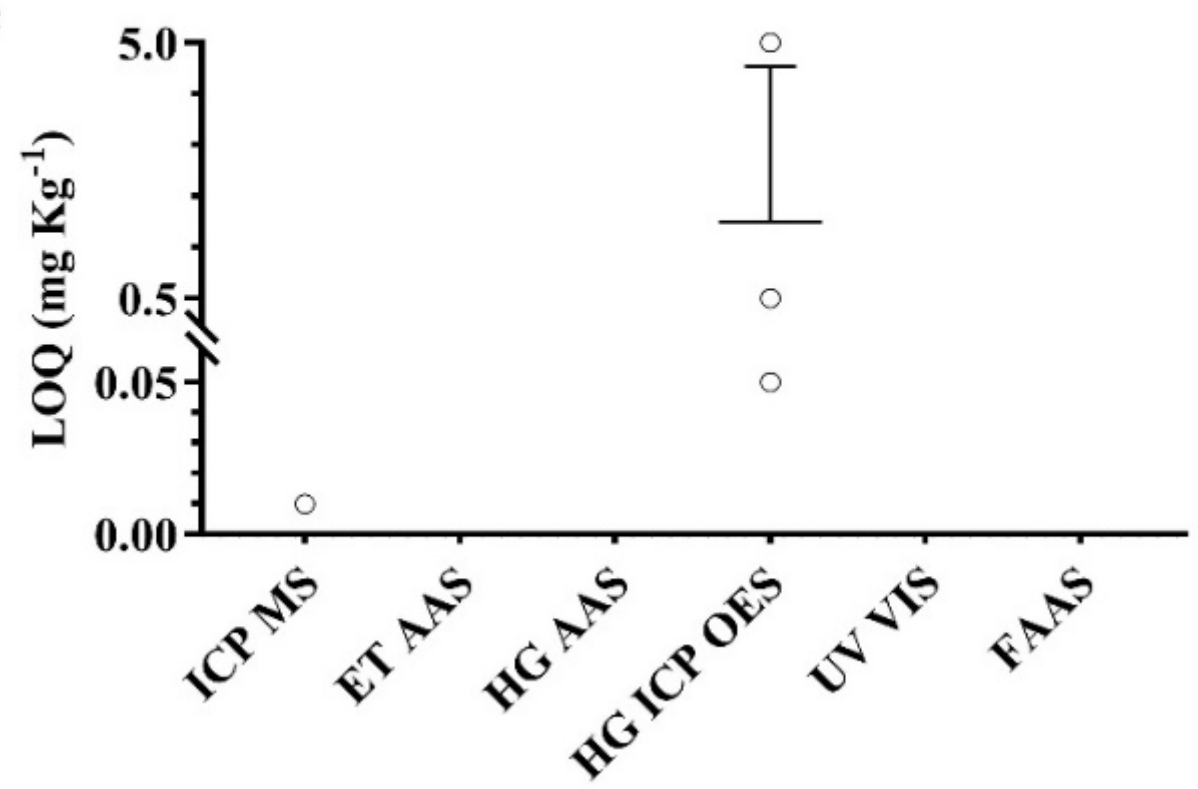

Figure 2. LOQ (Limits of quantification) of As per analytical technique, in liquid (a), solid (b) and bioindicator samples (c) and comparison with legal environmental limits of potability and value of prevention (VP) for soil. 
Table 2 present the LOQ for As obtained using different analytical technique and compare it with that showed in studies involving As quantification in the three matrices considered in the present data survey.

Table 2. LOQ (Limits of quantification) of As per analytical technique in liquid, solid and bioindicator samples observed in the present data survey and comparison with other works.

\begin{tabular}{|c|c|c|}
\hline Technique & LOQ & Reference \\
\hline \multicolumn{3}{|c|}{ Liquid samples $\left(\mu \mathrm{g}^{-1}\right)$} \\
\hline ICP MS & 0.0007 & (Bolea-Fernandez et al. 2015) \\
\hline ET AAS & 0.006 & (Hassanpoor et al. 2015) \\
\hline ICP MS & 0.04 to 4.00 & Data survey \\
\hline ET AAS & 0.05 to 10.00 & Data survey \\
\hline HG ICP OES & 0.10 to 10.00 & Data survey \\
\hline HG AAS & 0.10 to 11.00 & Data survey \\
\hline ICP MS & 0.21 & (Komorowicz and Barałkiewicz 2016) \\
\hline ICP MS & 0.33 & (García-Rico et al. 2019) \\
\hline HG AAS & 0.33 & (Akter et al. 2005) \\
\hline HG AAS & 0.41 & (Waterlot and Douay 2015) \\
\hline ICP MS & 0.46 & (Makowska et al. 2018) \\
\hline ICP MS & 0.70 & (Machado et al. 2017) \\
\hline UV VIS & 4.00 to 10.00 & Data survey \\
\hline ET AAS & 4.60 & (Makowska et al. 2018) \\
\hline \multicolumn{3}{|c|}{ Solid samples ( $\left.\mu \mathrm{g} \mathrm{kg}^{-1}\right)$} \\
\hline HG AAS & 0.67 & (Gürleyük et al. 2000) \\
\hline HG ICP OES & 1.00 to 20,000 & Data survey \\
\hline ICP MS & 1.50 to 1,000 & Data survey \\
\hline ET AAS & 7.40 & (Nielsen et al. 2011) \\
\hline HG AAS & 10.0 to 6,000 & Data survey \\
\hline TXRF & 33.3 & (Pierangeli et al. 2015) \\
\hline HG ICP OES & 50.0 & (Souza et al. 2016) \\
\hline HG ICP OES & 50.0 & (Alcântara et al. 2011) \\
\hline ET AAS & 50.0 to 1,000 & Data survey \\
\hline HG ICP OES & 210 & (Paye et al. 2010) \\
\hline HG AAS & 300 & (Rezende et al. 2011) \\
\hline GC ECD & 480 & (Zhong et al. 2019) \\
\hline HG ICP OES & 830 & (Kim et al. 2019) \\
\hline PXRF & 1,670 & (Kim et al. 2019) \\
\hline ICP OES & 12,800 & (Paye et al. 2010) \\
\hline PXRF & 33,300 & (García-Rico et al. 2019) \\
\hline FAAS & 100,000 & Data survey \\
\hline
\end{tabular}


Table 2. Continued.

\begin{tabular}{lll}
\hline Technique & LOQ & \multicolumn{1}{c}{ Reference } \\
\hline ET AAS & \multicolumn{1}{c}{ Bioindicator samples $\left(\boldsymbol{\mu g} \mathbf{~ k g}^{-1}\right)$} \\
ICP MS & 0.08 & (Baig et al. 2010) \\
ICP MS & 0.09 & (Khan et al. 2015) \\
ICP MS & 0.12 & (Kaya and Turkoglu 2017) \\
ICP MS & 2.27 & (Oroian et al. 2016) \\
ICP MS & 10.0 & Data survey \\
HG ICP OES & 13.3 & (De La Cruz et al. 2018) \\
MIP OES & 50.0 to 5,000 & Data survey \\
ET AAS & 76.7 & (Gallego Ríos et al. 2018) \\
HG AFS & 100 & (Pereira et al. 2016) \\
ET AAS & 200 & (Wang et al. 2016) \\
\hline
\end{tabular}

In our data survey, it was possible to observe that the ICP MS presented a LOQ ranging from 0.04 to $4.00 \mu \mathrm{g} \mathrm{L}^{-1}$ in liquids, 1.50 to $1,000 \mu \mathrm{g} \mathrm{kg}^{-1}$ in solids and $10.00 \mu \mathrm{kg}^{-1}$ in bioindicators (Table 2). However, in water samples, some studies have considerably lower LOQ, such as $0.0007 \mu \mathrm{g} \mathrm{L} \mathrm{L}^{-1}$ (Bolea-Fernandez et al., 2015). But most values observed are close to the range (0.04 to $4.00 \mu \mathrm{g} \mathrm{L}^{-1}$ ), such as $0.21 \mu \mathrm{g} \mathrm{L}^{-1}$ (Komorowicz and Barałkiewicz, 2016), $0.33 \mu \mathrm{g} \mathrm{L}^{-1}$ (García-Rico et al., 2019), $0.46 \mu \mathrm{g} \mathrm{L}^{-1}$ (Kilic et al., 2018) and $0.70 \mu \mathrm{g} \mathrm{L}^{-1}$ (Machado et al., 2017). In bioindicators, some studies showed values close to those observed in the present data survey, while others showed lower values. For example, Khan et al. (2015) obtained $0.09 \mu \mathrm{g} \mathrm{kg}^{-1}$ when analyzing algae and Kaya and Turkoglu (2017) found $0.12 \mu \mathrm{g}$ $\mathrm{kg}^{-1}$ in fish samples. Oroian et al. (2016) observed $2.27 \mu \mathrm{g} \mathrm{kg}^{-1}$ in honey samples and De La Cruz et al. (2018) found $13.3 \mu \mathrm{g}$ $\mathrm{kg}^{-1}$ in plant tissues.

The ET AAS showed a LOQ between 0.05 and $10.00 \mu \mathrm{g} \mathrm{L}^{-1}$ in liquid samples and between 50.0 and 1,000 $\mu \mathrm{g}$ $\mathrm{kg}^{-1}$ in solids (Table 2). Studies using the same technique also present similar results in liquids ranging from $0.006 \mu \mathrm{g} \mathrm{L}^{-1}$ (Hassanpoor et al., 2015) and $4.60 \mu \mathrm{g} \mathrm{L}^{-1}$ (Makowska et al., 2018). In solid samples (soils), Nielsen et al. (2011) obtained a considerably lower value $\left(7.40 \mu \mathrm{g} \mathrm{kg}^{-1}\right)$ than the present data survey. Baig et al. (2010) obtained $0.08 \quad \mu \mathrm{g} \quad \mathrm{kg}^{-1}$ in bioindicator samples (corn) and Oliveira et al. (2016) reported $257 \mu \mathrm{gg}^{-1}$ when analyzing rice. Already Pereira et al. (2016) found $100 \mu \mathrm{g} \mathrm{kg}^{-1}$ when analyzing fish oil.

The two techniques that use $\mathrm{HG}$ presented similar LOQ values. The HG AAS had a LOQ ranging from 0.1 to $11 \mu \mathrm{g} \mathrm{L} \mathrm{L}^{-1}$ in liquid samples and from 10 to $6,000 \mu \mathrm{g} \mathrm{kg}$ 1 in solid samples; while the HG ICP OES ranged from 0.1 to $10 \mu \mathrm{g} \mathrm{L}^{-1}$ in liquid samples, from 1.0 to $20,000 \mu \mathrm{g} \mathrm{kg}^{-1}$ in solid samples and from 50 to $5,000 \mu \mathrm{g} \mathrm{kg}^{-1}$ in bioindicators (Table 2). Other studies using HG presented values within the same ranges found. When using HG AAS to analyze water, Akter et al. (2005) obtained $0.33 \mathrm{\mu g} \mathrm{L}^{-1}$ and Waterlot and Douay (2015) $0.41 \mu \mathrm{g} \mathrm{L}^{-1}$. In soils Gürleyük et al. (2000) obtained $0.67 \mu \mathrm{gg}^{-1}$, and in sediments Rezende et al. (2011) found $300 \mu \mathrm{g} \mathrm{kg-1}$. When using HG ICP OES to analyze soils, Souza et al. (2016) and Alcântara et al. (2011) obtained $50.0 \mu \mathrm{g} \mathrm{kg}^{-1}$, Paye et al. (2010) $210 \mu \mathrm{g} \mathrm{kg}^{-1}$ and Kim et al. (2019) $830 \mu \mathrm{g} \mathrm{kg}-1$.

Some techniques are used by few laboratories, such as UV VIS and FAAS. The UV VIS had a LOQ ranging from 4 to $10 \mu \mathrm{g}$ $\mathrm{L}^{-1}$ in liquid samples and FAAS presented 
$100,000 \mu \mathrm{g} \mathrm{kg}^{-1}$ in solid samples (Table 2). These techniques are also less used in scientific works, which in addition to the techniques previously discussed, use techniques that involve fluorescence, microwave induced plasma, electron capture detector and X-ray in diverse matrices. In soil samples, Pierangeli et al. (2015) used TXRF and obtained $33.3 \mu \mathrm{g} \mathrm{L}^{-1}$, Zhong et al. (2019) with gas chromatograph with an electron capture detector (GC ECD) found $480 \mu \mathrm{gg}^{-1}$ and Kim et al. (2019) with PXRF reported $1,670 \mu \mathrm{gg}^{-1}$. Analyzing samples in fish, Gallego Ríos et al. (2018) obtained $76.7 \mu \mathrm{g}$ $\mathrm{kg}^{-1}$ using MIP OES and in samples of Eisenia fetida, Wang et al. (2016) obtained $200 \mu \mathrm{g} \mathrm{kg}^{-1}$ with HG AFS.

Table 3 present the LOQ for As species obtained using different analytical techniques and compare it with that showed in studies involving As quantification in the three matrices considered in the present data survey. Only one laboratory is accredited for As speciation. However, it does not cover all species analyzed in scientific studies, quantifying only the species As III, As V, Monomethyl Arsenic (MMA), Dimethyl Arsenic (DMA) and Arsenic Betaine (AsB). Species such as trimethylarsine oxide (TMAO) found in plants (Bergqvist and Greger, 2012) or Arsenocoline (AsC) found in marine animals (Raber et al. 2012), are not accredited by any Brazilian laboratory.

The LOQ for As species in liquid samples was $0.25 \mu \mathrm{g} \mathrm{L}^{-1}$ (Table 3) for As III, As V, MMA, DMA and AsB. These values are similar to other reports which used similar techniques to determine As species. One study presented a lower LOQ when using solid phase extraction (SPE) coupled to ET AAS, obtaining $0.006 \mu \mathrm{g} \mathrm{L}^{-1}$ in the determination of $\mathrm{As}(\mathrm{III})$ and $\mathrm{As}(\mathrm{V})$, but it should be noted that other species were not determined (Hassanpoor et al. 2015). Using high performance liquid chromatography (HPLC) combined with ICP MS, Liu e Cai (2013) obtained values between 0.13 and $1.66 \mu \mathrm{g} \mathrm{L}^{-1}$, Komorowicz and Barałkiewicz (2016) between 0.22 and $0.39 \mu \mathrm{g} \mathrm{L}^{-1}$ and Cheng et al. (2018) between 3.00 and $5.90 \mu \mathrm{g} \mathrm{L}^{-1}$ for the determination of As III, As V, MMA, and DMA. Where in addition to the previous species, Komorowicz and Barałkiewicz (2016) also determined AsB and Liu and Cai (2013) quantified ROX and AsA. Akter et al. (2005) used HG AAS and obtained between 0.33 and $0.63 \mu \mathrm{g} \mathrm{L}^{-1}$ for determination of As III and DMA. Waterlot and Douay (2015) found $0.41 \mu \mathrm{g} \mathrm{L}^{-1}$ when determining As III and V by the same technique. Using LC ICP MS, Akter et al. (2005) obtained between 0.33 and $0.67 \mu \mathrm{g}$ $\mathrm{L}^{-1}$ for the determination of As III, As V, DMA and MMA. Some studies have higher LOQ values because they use less sensitive techniques, such as Gürkan et al. (2015) that obtained $3.00 \mu \mathrm{g} \mathrm{L}^{-1}$ for As V when using UV VIS. With CE UV Lee et al. (2018) obtained values between 7.90 and $20.0 \mu \mathrm{g}$ $\mathrm{L}^{-1}$ for As III, As V, MMA and DMA and Akter et al. (2005) reported between 300 and $1600 \mu \mathrm{g} \mathrm{L}^{-1}$ for As III, As V and DMA.

For As species in solid samples and bioindicators, the LOQ was $12.5 \mu \mathrm{g} \mathrm{kg}-1$ (Table 3) for As III, As V, MMA, DMA and AsB. The LOQ of the laboratories was considerably lower than those achieved by Wang et al. (2018) which obtained values between 400 and $1000 \mu \mathrm{g} \mathrm{kg}^{-1}$ for the determination of As III, V, DMA and MMA in Eisenia fetida using $\mathrm{HG}$ AFS. Other studies obtained smaller LOQ values in several matrices and analytical techniques, mostly using HPLC HG ICP OES, as in Khan et al. (2015) with LOQ between 0.06 and $0.20 \mu \mathrm{g} \mathrm{kg}^{-1}$ for MMA, AsB, As V, DMA, AsC and As III in algae. For quantification of As(III), As(V), MMA and DMA using same technique, García-Rico et al. (2019) found values ranging from $0.40 \mathrm{up}$ to $0.70 \mu \mathrm{g} \mathrm{L}^{-1}$ in urine. Ma et al. (2016) found values between 0.70 and $3.00 \mu \mathrm{g} \mathrm{kg}^{-1}$ in rice and Al-Assaf et al. (2009) reported values between 1.30 and $3.30 \mu \mathrm{g} \mathrm{L}^{-1}$ in soils. Using HPLC ICP MS, Wolf et al. (2011) obtained $0.05 \mu \mathrm{g} \mathrm{L}^{-1}$ for As III and V in soils. Working with rice samples, Wang et al. (2018) showed As values ranging from 0.70 and $3.00 \mu \mathrm{g} \mathrm{kg}^{-1}$ with HG AFS. Zhu et al. (2017) found lower values between 0.10 and $0.20 \mu \mathrm{g} \quad \mathrm{L}^{-1}$ with ion 
chromatography (IC) combined with ICP MS. Using HG AAS, Santos et al. (2018) obtained values between 0.07 and $0.10 \mu \mathrm{g}$ $\mathrm{L}^{-1}$ for As III and $\mathrm{V}$ in fish.

Table 3. LOQ (Limits of quantification) of As species per analytical technique, in liquid, solid and bioindicator samples observed in the present data survey and comparison with other works.

\begin{tabular}{|c|c|c|}
\hline Technique & LOQ & Reference \\
\hline \multicolumn{3}{|c|}{ Liquid samples $\left(\mu \mathrm{g} \mathrm{L}^{-1}\right)$} \\
\hline SPE ET AAS & 0.006 & (Hassanpoor et al. 2015) \\
\hline HPLC ICP MS & 0.13 to 1.66 & (Liu and Cai 2013) \\
\hline HPLC ICP MS & 0.22 to 0.39 & (Komorowicz and Barałkiewicz 2016) \\
\hline HPLC ICP MS & 0.25 & Data survey \\
\hline HG AAS & 0.33 to 0.63 & (Akter et al. 2005) \\
\hline LC ICP MS & 0.33 to 0.67 & (Akter et al. 2005) \\
\hline HG AAS & 0.41 & (Waterlot and Douay 2015) \\
\hline HPLC ICP MS & 3.00 to 5.90 & (Cheng et al. 2018) \\
\hline UV VIS & 3.00 & (Gürkan et al. 2015) \\
\hline CE UV & 7.90 to 20.0 & (Lee et al. 2018) \\
\hline CE UV & 300 to 1,600 & (Akter et al. 2005) \\
\hline \multicolumn{3}{|c|}{ Solid and bioindicator samples ( $\mu \mathrm{g} \mathrm{kg}^{-1}$ ) } \\
\hline HPLC HG ICP OES & 0.06 to 0.20 & (Khan et al. 2015) \\
\hline HPLC HG ICP OES & 0.40 to 0.70 & (García-Rico et al. 2019) \\
\hline HPLC HG ICP OES & 0.70 to 3.00 & (Ma et al. 2016) \\
\hline HPLC HG ICP OES & 1.30 to 3.30 & (Al-Assaf et al. 2009) \\
\hline HPLC ICP MS & 0.05 & (Wolf et al. 2011) \\
\hline HG AFS & 0.70 to 3.00 & (Wang et al. 2018) \\
\hline IC ICP MS & 0.10 to 0.20 & (Zhu et al. 2017) \\
\hline HG AAS & 0.07 to 0.10 & (Santos et al. 2018) \\
\hline HPLC ICP MS & 12.5 & Data survey \\
\hline HG AFS & 400 to 1,000 & (Wang et al. 2016) \\
\hline
\end{tabular}

\section{Conclusions}

There is a wide discrepancy between the number of accredited laboratories and analytical techniques by state and region in Brazil. A strong correlation was observed between the GDP and the number of accredited laboratories. Almost all laboratories were able to confirm environmental contamination, since they presented LOQ values inferior to environmental threshold. Analytical techniques sorted from lowest to highest LOQ values are: ICP
MS, ET AAS, HG AAS or HG ICP OES and UV VIS for liquid matrices; HG ICP OES, ICP MS, HG AAS, ET AAS and FAAS for solids; and ICP MS, HG and ICP OES for bioindicators. Only one laboratory is accredited for the analysis of As species but does not cover all species.

\section{Acknowledgements}

The authors gratefully acknowledge the financial support from the Brazilian Agencies Coordenação de Aperfeiçoamento de Pessoal de Nível 
Superior (CAPES), Conselho Nacional de Desenvolvimento Científico e Tecnológico (CNPq), and Fundação de Amparo a Pesquisa do Estado de Minas Gerais (Fapemig).

\section{Conflict of interests}

Authors declare that they have no conflict of interests.

\section{References}

Abdul, K. S. M.; Jayasinghe, S. S.; Chandana, E. P. S.; Jayasumana, C.; Silva, P. M. C. S. Arsenic and human health effects: A review. Environmental Toxicology and Pharmacology, v. 40, no. 3, p. 828-846, 2015. https://doi.org/10.1016/j.etap.2015.09.016

Akter, K. F.; Chen, Z.; Smith, L.; Davey, D.; Naidu, R. Speciation of arsenic in ground water samples: A comparative study of CE-UV, HG-AAS and LC-ICP-MS. Talanta, v. 68, no. 2, p. 406-415, 2005. https://doi.org/10.1016/ j.talanta.2005.09.011

Al-Assaf, K. H.; Tyson, J. F.; Uden, P. C. Determination of four arsenic species in soil by sequential extraction and high performance liquid chromatography with post-column hydride generation and inductively coupled plasma optical emission spectrometry detection. Journal of Analytical Atomic Spectrometry, v. 24, p. 376-384, 2009. https://doi.org/10.1039/b820300h

Alcântara, A. J. O.; Pierangeli, M. A. P.; Souza, C. A.; Souza, J. B. Teores de As, Cd, Pb, Cr e Ni e atributos de fertilidade de Argissolo Amarelo distrófico usado como lixão no Município de Cáceres, Estado de Mato Grosso. Revista Brasileira de Geociências, v. 41, p. 539-548, 2011. https://doi.org/10.25249/03757536.2011413539548

Baig, J. A.; Kazi, T. G.; Shah, A. Q.; Arain, M. B.; Afridi, H. I.; Khan, S.; Kandhro, G. A.; Naeemullah; Soomro, A. S. Evaluating the accumulation of arsenic in maize (Zea mays L.) plants from its growing media by cloud point extraction. Food and Chemical Toxicology,

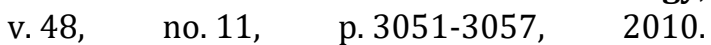
https://doi.org/10.1016/j.fct.2010.07.043

Bergqvist, C.; Greger, M. Arsenic accumulation and speciation in plants from different habitats. Applied Geochemistry, v. 27, no. 3, p. 615-622, 2012. https://doi.org/10.1016/ j.apgeochem.2011.12.009

Bidone, E.; Cesar, R.; Santos, M. C.; Sierpe, R.; Silva-Filho, E. V.; Kutter, V.; Silva, L. I. D.; Castilhos, Z. Mass balance of arsenic fluxes in rivers impacted by gold mining activities in Paracatu (Minas Gerais State, Brazil). Environmental Science and Pollution Research, v. 25, no. 9, p. 9085-9100, 2018. https://doi.org/10.1007/s11356-018-1215-z

Bolea-Fernandez, E.; Balcaen, L.; Resano, M.; Vanhaecke, F. Interference-free determination of ultra-trace concentrations of arsenic and selenium using methyl fluoride as a reaction gas in ICP-MS/MS. Analytical and Bioanalytical Chemistry, v. 407 p. 919-929, 2015. https://doi.org/10.1007/s00216-0148195-8

Borba, R. P.; Figueiredo, B. R.; Cavalcanti, J. A. Arsênio na água subterrânea em Ouro Preto e Mariana, Quadrilátero Ferrífero (MG). Rem: Revista Escola de Minas, v. 57, no. 1, p. 45-51, 2004. https://doi.org/10.1590/S0370-4467 2004000100009

Borba, R. P.; Figueiredo, B. R.; Matschullat, J. Geochemical distribution of arsenic in waters, sediments and weathered gold mineralized rocks from Iron Quadrangle, Brazil. Environmental Geology, v. 44, p. 39-52, 2003. https://doi.org/10.1007/s00254-002-0733-6

Brasil. CONAMA Resolution 357, March 17, 2005. Establishes provisions for the classification of water bodies as well as environmental directives for their framework, establishes conditions and standards for effluent releases and makes other provisions. Available from: <http://www2.mma.gov.br/ port/conama/processos/61AA3835/CONAMA -ingles.pdf\#page=300>. Accessed on: Oct. 13, 2018.

Brasil. CONAMA Resolution 420, December 28, 2009. Establishes provisions for the criteria and guiding values regarding soil quality and the presence of chemical substances and establishes directives for the environmental management of contaminated areas by those substances due to anthropic practices. Available from: <http://www2.mma. gov.br/port/conama/processos/61AA3835/C ONAMA-ingles.pdf\#page $=748>$. Accessed on: Oct. 15, 2018.

Brasil. CONAMA Resolution 430, May 13, 2011. Provisions the conditions and standards 
of effluents and complements and changes Resolution 357 from March 17, 2005 issued by the National Environment Council (CONAMA). Available from: <http://www2.mma. gov.br/port/conama/processos/61AA3835/C ONAMA-ingles.pdf\#page $=339>$. Accessed on: Oct. 16, 2018.

Brasil. Portaria de Consolidação no 5, de 28 de setembro de 2017. Consolidação das normas sobre as ações e os serviços de saúde do Sistema Único de Saúde. Available from: <https://portalarquivos2.saude.gov.br/images /pdf/2018/marco/29/PRC-5-Portaria-deConsolida----o-n---5--de-28-de-setembro-de2017.pdf>. Accessed on: Oct. 16, 2018.

Bundschuh, J.; Litter, M. I.; Parvez, F.; RománRoss, G.; Nicolli, H. B.; Jean, J.-S.; Liu, C.-W.; López, D.; Armienta, M. A.; Guilherme, L. R. G.; Cuevas, A. G.; Cornejo, L.; Cumbal, L.; Toujaguez, R. One century of arsenic exposure in Latin America: A review of history and occurrence from 14 countries. Science of The Total Environment, v. 429, p. 2-35, 2012. https://doi.org/10.1016/j.scitotenv.2011.06.0 24

Cheng, H.; Shen, L.; Liu, J.; Xu, Z.; Wang, Y. Coupling nanoliter high-performance liquid chromatography to inductively coupled plasma mass spectrometry for arsenic speciation. Journal of Separation Science, v. 41, p. 15241531, 2018. https://doi.org/10.1002/ jssc. 201701178

Costa, R. V. F.; Leite, M. G. P.; Mendonça, F. P. C.; Nalini Jr., H. A. Geochemical mapping of arsenic in surface waters and stream sediments of the Quadrilátero Ferrífero, Brazil. Rem: Revista Escola de Minas, v. 68, p. 43-51, 2015. https://doi.org/10.1590/0370-44672015 680077

De La Cruz, A.; Ferreira, L.; Andrade, V.; Gioda, A. Biomonitoring of toxic elements in plants collected near leather tanning industry. Journal of the Brazilian Chemical Society, v. 30, p. 256-264, 2018. https://doi.org/ 10.21577/0103-5053.20180174

Deschamps, E.; Ciminelli, V. S. T.; Lange, F. T.; Matschullat, J.; Raue, B.; Schmidt , H. Soil and sediment geochemistry of the Iron Quadrangle, Brazil: The case of arsenic. Journal of Soils Sediments, v. 2, no. 4, p. 216-222, 2002. https://doi.org/10.1007/BF02991043

Gallego Ríos, S. E.; Ramírez, C. M.; López, B. E.; Macías, S. M.; Leal, J.; Velásquez, C. M.
Evaluation of mercury, lead, arsenic, and cadmium in some species of fish in the Atrato River Delta, Gulf of Urabá, Colombian Caribbean. Water, Air \& Soil Pollution, v. 229, p. 275, 2018. https://doi.org/10.1007/ s11270-018-3933-8

García-Rico, L.; Meza-Figueroa, D.; Jay Gandolfi, A.; Rivero, C. I.; Martínez-Cinco, M. A.; MezaMontenegro, M. M. Health risk assessment and urinary excretion of children exposed to arsenic through drinking water and soils in Sonora, Mexico. Biological Trace Element Research, v. 187, no. 1, p.9-21, 2019. https://doi.org/10.1007/s12011-018-1347-5

Grochau, I. H.; Caten, C. S.; Camargo Forte, M. M. Current American landscape in laboratory accreditation according to ISO/IEC 17025. Accreditation and Quality Assurance, v. 22, no. 2, p. 57-62, 2017. https://doi.org/10.1007/ s00769-017-1248-x

Gürkan, R.; Kır, U.; Altunay, N. Development of a simple, sensitive and inexpensive ion-pairing cloud point extraction approach for the determination of trace inorganic arsenic species in spring water, beverage and rice samples by UV-Vis spectrophotometry. Food $\begin{array}{lll}\text { Chemistry, } & \text { v. } 180, \quad \text { p. } 32-41, \quad 2015 .\end{array}$ https://doi.org/10.1016/j.foodchem.2015.01. 142

Gürleyük, H.; Tyson, J. F.; Uden, P. C. Determination of extractable arsenic in soils using slurry sampling-on-line microwave extraction-hydride generation-atomic absorption spectrometry. Spectrochimica Acta Part B: Atomic Spectroscopy, v. 55, no. 7, p.935-942, 2000. https://doi.org/ 10.1016/S0584-8547(00)00196-8

Hassanpoor, S.; Khayatian, G.; Azar, A. R. J. Ultra-trace determination of arsenic species in environmental waters, food and biological samples using a modified aluminum oxide nanoparticle sorbent and AAS detection after multivariate optimization. Microchimica Acta, v. 182, no. $11 / 12$, p. 1957-1965, 2015. https://doi.org/10.1007/s00604-015-1532-6

Hung, D. Q.; Nekrassova, O.; Compton, R. G. Analytical methods for inorganic arsenic in water: a review. Talanta, v. 64, p. 269-277, 2004. https://doi.org/10.1016/j.talanta.2004. 01.027

Inmetro - Instituto Nacional de Metrologia, Qualidade e Tecnologia. Consulta ao Catálogo da RBLE. 2018. Available from: 
$<$ http://www.inmetro.gov.br/laboratorios/rbl e/>. Accessed on: Jul. 24, 2018.

Kaya, G.; Turkoglu, S. Bioaccumulation of heavy metals in various tissues of some fish species and green tiger shrimp (Penaeus semisulcatus) from İskenderun Bay, Turkey, and risk assessment for human health. Biological Trace Element Research, v. 180, no. 2, p. 314326, 2017. https://doi.org/10.1007/s12011017-0996-0

Khan, N.; Ryu, K. Y.; Choi, J. Y.; Nho, E. Y.; Habte, G.; Choi , H.; Kim, M. H.; Park, K. S.; Kim, K. S. Determination of toxic heavy metals and speciation of arsenic in seaweeds from South Korea. Food Chemistry, v. 169, p. 464-470, 2015. https://doi.org/10.1016/j.foodchem. 2014.08.020

Kilic, S.; Cengiz, M. F.; Kilic, M. Monitoring of metallic contaminants in energy drinks using ICP-MS. Environmental Monitoring and $\begin{array}{llll}\text { Assessment, } & \text { v. } 190, & \text { p. } 202, \quad 2018 .\end{array}$ https://doi.org/10.1007/s10661-018-6590-X

Kim, H.-R.; Kim, K.-H.; Yu, S.; Moniruzzaman, M.; Hwang, S.-I. ; Lee, G.-T.; Yuna, S.-T. Better assessment of the distribution of $\mathrm{As}$ and $\mathrm{Pb}$ in soils in a former smelting area, using ordinary co-kriging and sequential Gaussian cosimulation of portable X-ray fluorescence (PXRF) and ICP-AES data. Geoderma, v. 341, p. 26-38, 2019. https://doi.org/10.1016/ j.geoderma.2019.01.031

Komorowicz, I.; Barałkiewicz, D. Determination of total arsenic and arsenic species in drinking water, surface water, wastewater, and snow from Wielkopolska, Kujawy-Pomerania, and Lower Silesia provinces, Poland. Environmental Monitoring and Assessment, v. 188, 2016. https://doi.org/10.1007/s10661-016-5477-y

Lee, H. G.; Kwon, J. Y.; Chung, D. S. Sensitive arsenic speciation by capillary electrophoresis using UV absorbance detection with on-line sample preconcentration techniques. Talanta, v. 181 , p. $366-372,2018$. https://doi.org/ 10.1016/j.talanta.2018.01.034

Liu, G.; Cai, Y. Studying arsenite-humic acid complexation using size exclusion chromatography-inductively coupled plasma mass spectrometry. Journal of Hazardous Materials, v. 262, p. 1223-1229, 2013. https://doi.org/10.1016/j.jhazmat.2012.05.043

Liu, Q.; Lu, X.; Peng, H.; Popowich, A.; Tao, J.; Uppal, J. S.; Yan, X.; Boe, D.; Le, X. C. Speciation of arsenic: A review of phenylarsenicals and related arsenic metabolites. TrAC Trends in Analytical Chemistry, v. 104, p. 171-182, 2018. https://doi.org/10.1016/j.trac.2017. 10.006

Ma, J.; Sengupta, M. K.; Yuan, D.; Dasgupta, P. K. Speciation and detection of arsenic in aqueous samples: A review of recent progress in nonatomic spectrometric methods. Analytica Chimica Acta, v. 831, p. 1-23, 2014. https://doi.org/10.1016/j.aca.2014.04.029

Ma, L.; Wang, L.; Jia, Y.; Yang, Z. Arsenic speciation in locally grown rice grains from Hunan Province, China: Spatial distribution and potential health risk. Science of the Total Environment, v. 557-558, p. 438-444, 2016. https://doi.org/10.1016/j.scitotenv.2016.03.0 51

Machado, C. S.; Fregonesi, B. M.; Alves, R. I. S.; Tonani, K. A. A.; Sierra, J.; Martinis, B. S.; Celere, B. S.; Mari, M.; Schuhmacher, M.; Nadal, M.; Domingo, J. L.; Segura-Muñoz, S. Health risks of environmental exposure to metals and herbicides in the Pardo River, Brazil. Environmental Science and Pollution Research, v. 24, p. 20160-20172, 2017. https://doi.org/10.1007/s11356-017-9461-z

Makowska, D.; Strugała, A.; Wierońska, F.; Bacior, M. Assessment of the content, occurrence, and leachability of arsenic, lead, and thallium in wastes from coal cleaning processes. Environmental Science and Pollution Research, v. 26, p. 8418-8428, 2018. https://doi.org/10.1007/s11356-0183621-7

Moe, B.; Peng, H.; Lu, X.; Chen, B.; Chen, L. W. L.; Gabos, S.; Li, X.-F.; Le, C. Comparative cytotoxicity of fourteen trivalent and pentavalent arsenic species determined using real-time cell sensing. Journal of Environmental Sciences, v. 49, p. 113-124, 2016. https://doi.org/10.1016/j.jes.2016. 10.004

Nielsen, S. S.; Petersen, L. R.; Kjeldsen, P.; Jakobsen, R. Amendment of arsenic and chromium polluted soil from wood preservation by iron residues from water treatment. Chemosphere, v. 84, p. 383-389, 2011. https://doi.org/10.1016/j.chemosphere. 2011.03.069

Oliveira, R. M.; Antunes, A. C. N.; Vieira, M. A.; Medina, A. L.; Ribeiro, A. S. Evaluation of sample preparation methods for the 
determination of $\mathrm{As}, \mathrm{Cd}, \mathrm{Pb}$, and $\mathrm{Se}$ in rice samples by GF AAS. Microchemical Journal, v. 124 , p. $402-409,2016$. https://doi.org/ 10.1016/j.microc.2015.09.018

Ono, F. B.; Guilherme, L. R. G.; Penido, E. S.; Penido, E. S.; Carvalho, G. S.; Hale, B.; Toujaguez, R.; Bundschuh, J. Arsenic bioaccessibility in a gold mining area: A health risk assessment for children. Environmental Geochemistry and Health, v. 34, p. 457-465, 2012. https://doi.org/10.1007/s10653-0119444-9

Oroian, M.; Prisacaru, A.; Hretcanu, E. C.; Stroe, S.-G.; Leahu, A.; Buculei, A. Heavy metals profile in honey as a potential indicator of botanical and geographical origin. International Journal of Food Properties, $\begin{array}{llll}\text { v. } 19, \quad \text { p. } 8, \quad \text { p. } 1825-1836, & 2016 .\end{array}$ https://doi.org/10.1080/10942912.2015.110 7578

Paye, H. D. S.; Mello, J. W. V.; Abrahão, W. A. P.; Fernandes Filho, E. I.; Dias, L. C. P.; Castro, M. L. O.; Melo, S. B.; França, M. M. Valores de referência de qualidade para metais pesados em solos no Estado do Espírito Santo. Revista Brasileira de Ciência do Solo, v. 34, no. 6, p. 2041-2051, 2010. https://doi.org/ 10.1590/S0100-06832010000600028

Pereira, E. R.; Almeida, T. S.; Borges, D. L. G.; Carasek, E.; Welz, B.; Feldmann, J.; Menoyo, J. C. Investigation of chemical modifiers for the direct determination of arsenic in fish oil using high-resolution continuum source graphite furnace atomic absorption spectrometry. Talanta, v. $150, \quad$ p. $142-147,2016$. https://doi.org/10.1016/j.talanta.2015.12.036

Pierangeli, M. A. P.; Guilherme, L. R. G.; Carvalho, G. S.; Carvalho, C. A.; Silva, C. A.; Pierangeli, L. M. P. Elementos-traço em áreas de vegetação nativa e agricultura intensiva do Estado de Mato Grosso determinados por fluorescência de raios-x por reflexão total. Revista Brasileira de Ciência do Solo, v. 39, n. 4, p. 1048-1057, 2015. https://doi.org/ 10.1590/01000683rbcs20140373

Raber, G.; Stock, N.; Hanel, P.; Murko, M.; Navratilova, J.; Francesconi, K. A. An improved HPLC-ICPMS method for determining inorganic arsenic in food: Application to rice, wheat and tuna fish. Food Chemistry, v. 134, p. 524-532, 2012. https://doi.org/10.1016/ j.foodchem.2012.02.113
Rede Metrológica do Rio Grande do Sul. Laboratórios Reconhecidos - Rede Metrológica. 2018. Available from: <http://www.rede metrologica.com.br/laboratoriosreconhecidos>. Accessed on: Jul. 26, 2018

Rezende, P. S.; Costa, L. M.; Windmöller, C. C. Arsenic mobility in sediments from Paracatu River Basin, MG, Brazil. Archives of Environmental Contamination and Toxicology, v. 68, p. 588-602, 2015. https://doi.org/10.1007/s00244-015-0134-y

Rezende, P. S.; Moura, P. A. S.; Durão Jr., W. A.; Nascentes, C. C.; Windmöller, C. C.; Costa, L. M. Arsenic and Mercury mobility in Brazilian sediments from the São Francisco River Basin. Journal of the Brazilian Chemical Society, v. 22 , p. 910-918. https://doi.org/10.1590/ S0103-50532011000500014

RMMG - Rede Metrológica de Minas Gerais. Laboratórios reconhecidos. 2018. Available from: <https://www.rmmg.com.br/laborato riosreconhecidos $>$. Accessed on: Jul. 25, 2018.

Sankararamakrishnan, N.; Mishra, S. A comprehensive review on various analytical methods for the determination of inorganic and organic arsenic in environmental samples. In: Gupta T.; Agarwal, A.; Agarwal, R. L. N. (Ed.). Environmental contaminants. Energy, environment, and sustainability. Singapore: Springer, 2018. p. 21-41. https://doi.org/ 10.1007/978-981-10-7332-8_2

Santos, G. R.; Pales, R. C.; Rodrigues, S. G. Desigualdades regionais no Brasil - 1991-2010. InterSciencePlace, v. 1 , no. 31 , p. 145-173, 2014.

Santos, Q. O.; Silva Junior, M. M.; Lemos, V. A.; Ferreira, S. L. C.; Andrade, J. B. An online preconcentration system for speciation analysis of arsenic in seawater by hydride generation flame atomic absorption spectrometry. Microchemical Journal, v. 143, p. 175-180, 2018. https://doi.org/10.1016/ j.microc.2018.08.004

Silva, D.; Bellato, C.; Marques Neto, J.; Fontes, M. Arsenic and trace metals in water and sediment of the Velhas River, Southeastern Iron Quadrangle Region, Minas Gerais, Brazil. Quimica Nova, v. 41, p. 1011-1018, 2018. https://doi.org/10.21577/0100-4042.2017 0275 
Souza, L. C.; Campos, M. L.; Reichert, G.; Moura, C. N. Teores de arsênio em solos de três regiões do Estado de Santa Catarina. Revista Ambiente \& Água, v. 11, p. 135-144, 2016. https://doi.org/10.4136/ambi-agua.1746

Varejão, E. V. V.; Bellato, C. R.; Fontes, M. P. F.; Mello, J. W. V. Arsenic and trace metals in river water and sediments from the Southeast portion of the Iron Quadrangle, Brazil. Environmental Monitoring and Assessment, v. 172, no. 1/4, p.631-642, 2011. https://doi.org/10.1007/s10661-010-1361-3

Wang, Y.; Li, Y.; Lv, K.; Chen, X.; Yu, X. A simple and sensitive non-chromatographic method for quantification of four arsenic species in rice by hydride generation-atomic fluorescence spectrometry. Spectrochimica Acta Part B: Atomic Spectroscopy, v. 149, p.197-202, 2018. https://doi.org/10.1016/j.sab.2018. 08.012

Wang, Z.; Cui, Z.; Xu, X. Lysosomal membrane response of the earthworm, Eisenia fetida, to arsenic species exposure in OECD soil. RSC Advances, v. 6, p. 23498-23507, 2016. https://doi.org/10.1039/C5RA27725F

Waterlot, C.; Douay, F. Arsenic mobility and speciation in contaminated kitchen garden and lawn soils: An evaluation of water for assessment of As phytoavailability. Environmental Science and Pollution Research, v. 22, p.6164-6175, 2015. https://doi.org/10.1007/s11356-014-3829-0
Wolf, R. E.; Morman, S. A.; Hageman, P. L.; Hoefen, T. M.; Plumlee, G. S. Simultaneous speciation of arsenic, selenium, and chromium: Species stability, sample preservation, and analysis of ash and soil leachates. Analytical and Bioanalytical Chemistry, v. 401, p. 27332745, 2011. https://doi.org/10.1007/s00216011-5275-x

Yogarajah, N.; Tsai, S. S. H. Detection of trace arsenic in drinking water: Challenges and opportunities for microfluidics. Environmental Science: Water Research \& $\begin{array}{llll}\text { Technology, } & \text { v. } 1, & \text { p. } 426-447, & 2015 .\end{array}$ https://doi.org/10.1039/C5EW00099H

Zhong, L.; Ni, R.; Zhang, L.; He, Z.; Zhou, H.; Li, L. Determination of total arsenic in soil by gas chromatography after pyrolysis. Microchemical Journal, v. 146, p.568-574, 2019. https://doi.org/10.1016/j.microc.2019. 01.057

Zhu, Q.; Cui, H.; Dong, L.; Shan, B.; Han, T.; Li, H.; Cai, F. Speciation of arsenic in rice by ion chromatography with online anion suppression and inductively coupled plasma mass spectrometry. Analitical Letters, v. 50, p. 1040-1048, 2017. https://doi.org/10.1080/ 00032719.2016 .1203927

License information: This is an open-access article distributed under the terms of the Creative Commons Attribution License, which permits unrestricted use, distribution, and reproduction in any medium, provided the original work is properly cited. 